ADAM LACHOWICZ (Białystok)

\title{
LAICYZACJA OPIEKI SPOŁECZNEJ W WOJEWÓDZTWIE BIAŁOSTOCKIM W LATACH 1945-1948
}

Forsowana w powojennej Polsce przez komunistów laicyzacja życia publicznego była stałym elementem ich polityki społecznej i wyznaniowej, stanowiła wciąż otwarte pole walki reżimu z katolicyzmem. Podstawowym celem laicyzacji było odsunięcie Kościoła od spraw społecznych i związane $\mathrm{z}$ tym osłabienie jego zewnętrznego oddziaływania i wewnętrznej spoistości. Centralnie sterowane procesy zeświecczania zagrażały nie tylko swobodzie działania i istnieniu instytucji kościelnych, ale także miały wyraźne antychrześcijańskie ostrze. Laicyzacja stosunków publicznych musiała prędzej czy później doprowadzić do zobojętnienia religijnego w życiu prywatnym, torując drogę ateizmowi programowo głoszonemu przez marksistów oraz zmniejszając odporność obywateli na sowietyzację.

Jednym $\mathrm{z}$ istotniejszych przejawów laicyzacji życia publicznego w pierwszych latach rządów ludzi Stalina w Polsce była sekularyzacja opieki społecznej, w województwie białostockim przed rokiem 1949 ogniskująca się głównie na sektorze wychowawczo-opiekuńczym. Polityka zeświecczania dotknęła szykanami nie tylko placówki zajmujące się młodzieżą i dziećmi, ale również zakłady opiekuńcze dla dorosłych i ludzi w podeszłym wieku oraz organizacje zajmujące się pomocą doraźną i akcjami charytatywnymi.

Początkowe przyzwolenie komunistów na funkcjonowanie sierocińców, przedszkoli, domów starców i innych ośrodków opiekuńczych prowadzonych przez zgromadzenia zakonne i "Caritas" było wymuszone niedostateczną liczbą placówek świeckich wobec ogromu zapotrzebowania na pomoc ze 
strony zubożałego w wyniku wojny społeczeństwa ${ }^{1}$. Podobnie, zgoda „władzy ludowej" na obecność w zakładach publicznych pracujących tam sióstr zakonnych spowodowana była brakiem wystarczającej liczby odpowiednio przeszkolonego personelu świeckiego.

O tolerancji wobec katolickich ośrodków pomocy decydowały również względy natury propagandowej, szczególnie ważne w okresie przez wyborami styczniowymi w 1947 r. Istnienie i działalność placówek kościelnych, często opisywanych w białostockiej prasie (zarówno w organie Wojewódzkiego Urzędu Informacji i Propagandy „Jedność Narodowa”, jak i w „Życiu Białostockim"), miały świadczyć o rzekomo pozytywnym stosunku obozu rządzącego do Kościoła. W gazetach często podkreślano dotowanie ośrodków zakonnych i "Caritasu” przez administrację państwowąi samorządową ${ }^{2}$. Władze afiszowały się wspieraniem finansowym zakładów wyznaniowych przede wszystkim w latach 1946-1947, tzn. w okresie przedwyborczym i po sfałszowaniu wyborów styczniowych 1947 r., kiedy to obozowi komunistycznemu zależało na akceptacji ze strony hierarchii Kościoła i katolickiej opinii publicznej.

W prasie lokalnej, obok artykułów opisujących w sposób obiektywny zaangażowanie Kościoła w rozwiązywanie problemów społecznych, pojawiały się głosy negujące doniosłość wkładu katolickiego w rozwój sfery opiekuńczej. Zarzucano "Caritasowi” i stowarzyszeniom zakonnym, że ich działalność nie jest prawdziwą pomocą, a jedynie jałmużną uwłaczającą godności ludzi potrzebujących. Na początku lipca 1945 r. w „Jedności Narodowej" (organie WUIiP) przedstawiono relację z pierwszego zjazdu referentów i pracowników opieki społecznej województwa białostockiego, który odbył się w dniach 29 i 30 czerwca 1945 r. w Urzędzie Wojewódzkim. W mowie otwierającej obrady wicewojewoda zaznaczył: „W myśl zasad państwa demokratycznego Opieka Społeczna nie jest czymś w rodzaju łaski, jest ko-

1 Np. na początku 1946 r. na 27 przedszkoli w Okręgu Szkolnym Białostockim 9 było prowadzonych przez zakony (Archiwum Państwowe w Białymstoku [dalej: AP w B], Kuratorium Okręgu Szkolnego Białostockiego [dalej: KOSB], syg. 88, k. 2, Ewidencja przedszkoli OSB na dzień 15 stycznia 1946 r.), a w październiku 1948 r. na 1037 dzieci w 12 białostockich przedszkolach à̇ 499 uczęszczało do 4 przedszkoli zarządzanych przez „Caritas" (AP w B, KOSB, syg. 24, Wykazy czynnych przedszkoli woj. białostockiego wg powiatów w roku szkolnym 1948/1949 - stan z października 1948 r., k. 1).

2 „Jedność Narodowa” nr 30 (121) z 10-12 marca 1946 r., nr 35 (126) z 22-23 marca 1946 r., nr 62 (153) z 18 maja 1946 r., nr 125 (216) z 1 sierpnia 1946 r.; „Życie Białostockie” nr 5 (848) z 5 marca 1947 r., nr 94 (937) z 5 czerwca 1947 r., nr 98 (941) z 9 czerwca 1947 r., nr 126 (969) z 7 lipca 1947 r., nr 263 (1106) z 22 listopada 1947 r. 
niecznością, obowiązkiem [...]" ${ }^{3}$. Słowa te wyrażały niechęć w stosunku do niezależnych organizacji charytatywnych oraz zamiar pomniejszenia ich roli w porównaniu z pomocą państwową.

W listopadzie 1945 r. Anatol Kraska w opublikowanym w „Jedności Narodowej" artykule atakującym w niewybredny sposób tę „,[..] część duchowieństwa województwa białostockiego, które znalazło się za burtą dzisiejszej rzeczywistości", zanegował potrzebę organizowania opieki społecznej przez Kościół w powojennej Polsce: „[...] masa pracująca, to już nie stado niewolników, których można zadowolić ochłapami z księżowskiego stołu w postaci «ofiar dla biednych» [...]" 4. W styczniu 1946 r. W. Walewska w tekście poświęconym Robotniczemu Towarzystwu Przyjaciół Dzieci pisała: „[...] wychowanie i opieka nad dzieckiem nie moga być oparte na uwłaczającej godności ludzkiej akcji filantropijnej, lecz na szeroko zakrojonym państwowym i społecznym planie działalności" 5 , w którym nie było miejsca dla zakonów i "Caritasu”. Z kolei latem 1947 r. „Życie Białostockie” w sprawozdaniu z pierwszego zjazdu delegatów RTPD w Warszawie 22 czerwca przedstawiło streszczenie referatu posłanki Kłuszyńskiej (pt. Postulaty RTPD w sprawach dziecka $w$ Polsce), która domagała się, aby wychowaniem i opieką nad dziećmi zajmowało się państwo tylko za pośrednictwem „instytucji specjalnych, korzystających z zagwarantowanych prawem przywilejów", nie pozwalając na żadne prywatne (w tym również katolickie) inicjatywy na tym polu ${ }^{6}$.

Polityka laicyzacji opieki społecznej w województwie białostockim przed 1949 r. przejawiała się m.in. w odbieraniu Kościołowi należących do niego lokali przeznaczonych na działalność opiekuńczą. Przypadki takie wiązały się z wyraźnym pogwałceniem prawa własności Kościoła i dotyczyły zarówno obiektów zakonnych, jak i parafialnych.

Latem 1945 r. białostocki sierociniec „Dobry Pasterz”, prowadzony przez zakonnice z Towarzystwa „Pomoc", pozbawiono prawa użytkowania znaczącej części własnego budynku. Na wniosek Wydziału Zdrowia Zarządu Miejskiego Komisja Mieszkaniowa IV Rejonu w Białymstoku decyzją

3 Ze zjazdu referentów i pracowników Opieki Społecznej, „Jedność Narodowa” nr 28, 8 lipca 1945 r., s. 3. s. $4-5$.

4 A. Kraska, Nie mogę milczeć..., „Jedność Narodowa” nr 70, 7-8 listopada 1945,

5 W. Walewska, Troska o dziecko, „Jedność Narodowa” nr 5 (96), 11-12 stycznia 1946, s. 4.

6 Powszechne wychowanie przedszkolne i pozaszkolne naczelnym zadaniem RTPD, „Życie Białostockie” nr 113 (956), 24 czerwca 1947 r., s. 2. 
z 16 czerwca 1945 r. odebrała sierocińcowi pomieszczenia na parterze piętrowego domu (wraz z kuchnią) i przekazała je nieodpłatnie do dyspozycji Wydziału Zdrowia w celu zorganizowania w nich Miejskiej Stacji Opieki nad Matką i Dzieckiem oraz Kuchni Mlecznej ${ }^{7}$ Zważywszy, że białostocki oddział Towarzystwa „Pomoc” posiadał jeszcze tylko parterowy budynek przeznaczony na potrzeby sióstr (znajdowała się w nim m.in. kaplica) utrata całego piętra $w$ siedzibie zakładu stanowiła niepowetowaną stratę uniemożliwiającą nie tylko rozwój, ale i normalne funkcjonowanie ${ }^{8}$.

Już 17 czerwca 1945 r. w „Jedności Narodowej” ukazał się entuzjastyczny artykuł poświęcony Miejskiej Stacji Opieki nad Matką i Dzieckiem. Autorka tekstu przemilczała sprawę eksmisji „Dobrego Pasterza”, a stację, która powstała kosztem sierocińca, nazwała „uwieńczeniem pracy władz w trosce o dziecko" ${ }^{9}$. Kierownictwo domu dziecka w kwietniu 1946 r. zwróciło się do Urzędu Kwaterunkowego Zarządu Miejskiego w Białymstoku z prośbą o przeniesienie stacji opieki do innego lokalu i zwrot pomieszczeń przez nią zajmowanych ${ }^{10}$. Siostry Pasterzanki zwróciły się też do Kuratorium Okręgu Szkolnego Białostockiego o poparcie ich starań w tym kierunku11. Miejska Stacja Opieki pomieszczenia należące do „Dobrego Pasterza" opuściła dopiero w sierpniu 1948 r., czyli na kilka miesięcy przed ogłoszeniem likwidacji sierocińca ${ }^{12}$.

7 AP.w B, KOSB, syg. 89, k. 30, Odpis orzeczenia Komisji Mieszkaniowej IV Rejonu w Białymstoku z 16 czerwca 1945 r. w sprawie wniosku Wydziału Zdrowia Zarządu Miejskiego w Białymstoku o przydzielenie lokalu na parterze domu Nr 5 przy ul. Orzeszkowej dla MSO nad M i D oraz dla Kuchni Mlecznej. Komisja Mieszkaniowa zobowiązała Zarząd Miejski jedynie do urządzenia domowi dziecka kuchni zastępczej w terminie do 1 lipca 1945 r. (do tego czasu sieroty miały prawo korzystać ze starej kuchni), ale w pomieszczeniach należących do towarzystwa.

8 AP w B, KOSB, syg. 89, k. 20, Protokół zdawczo-odbiorczy Komisji KOSB i Wydziału Opieki Społecznej Urzędu Wojewódzkiego Białostockiego oraz Zarządu Miejskiego w Białymstoku powołanej do lustracji Domu Dziecka „Dobry Pasterz” przy ul. Orzeszkowej 5 w Białymstoku z 3 stycznia 1946 r.; AP w B, KOSB, syg. 89, k. 33-34, Karta rejestracyjna zakładu wychowawczego pod nazwą Dom Dziecka „Dobry Pasterz” z 30 sierpnia $1946 \mathrm{r}$.

9 Szejkowa, Otwarcie instytucji zdrowia, „Jedność Narodowa” nr 22, 17 czerwca 1945 r., s. 5.

10 AP w B, KOSB, syg. 89, k. 29, Pismo kierownictwa Domu Dziecka „Dobry Pasterz" w Białymstoku do Urzędu Kwaterunkowego Zarządu Miejskiego w Białymstoku z 30 kwietnia 1946 r.

11 AP w B, KOSB, syg. 89, k. 31, Pismo kierownictwa Domu Dziecka „Dobry Pasterz” w Białymstoku do Kuratorium OSB z 23 maja 1946 r.

12 Nowy lokal Matki i Dziecka, „Życie Białostockie” nr 238 (1380), 29 sierpnia 1948, s. 3; Dzięki budowie nowego Domu Dziecka opieka nad sierotami przyjmie właściwy kierunek wychowawczy, „Życie Białostockie” nr 322 (1464), 22 listopada 1948, s. 3. 
Równie bulwersujące było zajęcie przez milicję domu parafialnego w Brańsku, w którym znajdowała się kuchnia „Caritasu” i w którym planowano zorganizować sierociniec. W 1946 r. garnizon Wojska Polskiego, tymczasowo rozlokowany w miasteczku, przejął od MO lokal posterunku. Zarząd Miejski wymógł wtedy na dziekanie brańskim ks. Kazimierzu Łomackim bezpłatne „użyczenie" części budynku parafialnego - przeznaczonej na sierociniec - dla milicji na krótki czas, najwyżej paromiesięczny, obiecu jąc niezwłocznie przystąpić do remontu odpowiedniego lokalu dla MO. Wkrótce wojsko wyjechało $\mathrm{z}$ Brańska, remont $\mathrm{w}$ projektowanym dla milicji lokalu został wykonany, a posterunek wbrew zapewnieniom Zarządu Miejskiego pozostał w lokalu kościelnym. Prośby ks. dziekana o to, by przynajmniej podpisać umowę dzierżawy, zostały zignorowane. Więcej, w końcu kwietnia 1947 r. Zarząd Miejski zażądał od ks. Łomackiego, aby opróżnił i przekazał posterunkowi pozostałą część domu parafialnego mieszczącą kuchnię "Caritasu". Ksiądz dziekan, bezsilny wobec przemocy nieliczących się z prawem organów władzy, w piśmie protestacyjnym do wojewody białostockiego dał wyraz swojemu oburzeniu:

„Dom, w którym się mieści kuchnia Caritasu i posterunek Milicji Obywatelskiej, jest bezsprzeczną własnością Kościoła i jako taka w myśl urzędowych oświadczeń najwyższych czynników państwowych nie może być w prawie własności ograniczona. [...] Lokal kuchni Caritas został przeze mnie odnowiony, przystosowany do użytku kuchennego, nie widzę racji przenoszenia się do cudzego domu mając swój, płacenia dzierźawy za cudzy lokal mając swój darmo, na nowo przystosowywać lokal dla kuchni i na nowo wydawać pieniądze przeznaczone na karmienie głodnych i chorych dzieci" ${ }^{13}$.

Zeświecczanie opieki społecznej władze komunistyczne przeprowadzały również przy pomocy zwolnień personelu zakonnego z zakładów państwowych i samorządowych. Już wiosną 1947 r. na posiedzeniu plenarnym Komitetu Wojewódzkiego PPR w Białymstoku w dniu 16 maja towarzysz Kubiak poruszył kwestię sprawowania funkcji opiekuńczo-wychowawczych w placówkach publicznych przez zakonnice. Uznał on, że powierzanie opieki nad dziećmi siostrom zakonnym jest błędem ${ }^{14}$. Na konsekwencje zainteresowa-

13 List dziekana brańskiego ks. K. Łomackiego do Wojewody Białostockiego w sprawie zajęcia własności kościelnej przez Milicję Obywatelską z 30 kwietnia 1947 r., w: P. Raina, Kościót..., s. 87-88.

14 AP w B, Komitet Wojewódzki Polskiej Partii Robotniczej w Białymstoku [dalej: KW PPR], syg. 1/II/1, Protokół plenarnego posiedzenia KW PPR w Białymstoku w dniu 16 maja 1947 r., s. 9. 
nia się sprawą na najwyższych szczeblach décydenckich w województwie nie trzeba było długo czekać.

Na przełomie maja i czerwca 1947 r. Miejski Dom Dziecka w Białymstoku został przeniesiony z ul. Sitarskiej do Zwierzyńca. Do czasu zmiany siedziby połowę personelu stanowiły siostry zakonne, które przy okazji przeprowadzki zostały zwolnione. Posunięcie to, pod względem politycznych priorytetów władz przemyślane, pod względem dobra dzieci i wymogów wychowawczo-opiekuńczych było nie tylko bezsensowne, ale nawet szkodliwe. W sierocińcu przy ul. Sitarskiej było 60 podopiecznych, nowy zakład w Zwierzyńcu przewidziany był dla $150 \bullet$ dzieci. Nowo przyjęte wychowawczynie na miejsce zakonnic nie miały praktyki ani kwalifikacji i trzeba było organizować dla nich specjalne szkolenie. Żadne merytoryczne powody nie uzasadniały pozbycia się dobrze przygotowanych do swojej pracy i zżytych z wychowankami sióstr w momencie, gdy dom dziecka miał się rozwijać. Były jednak powody ideologiczne - zakonnice na pewno nie wyszkoliłyby sierot na dobrych marksistów ${ }^{15}$.

Jesienią 1947 r. na posiedzeniu plenarnym KW PPR w Białymstoku w dniu 16 października tow. Kubiak ponownie podniósł sprawę doboru personelu w zakładach opiekuńczych. Napiętnował on zgodę rady zakładowej fabryki chemicznej w Hajnówce na zatrudnienie w przedszkolu zakładowym zakonnic w charakterze wychowawczyn ${ }^{16}$.

Decyzja o zwolnieniach personelu zakonnego w placówkach opieki społecznej na większą skalę zapadła jesienią 1948 r. Na dwudniowym posiedzeniu Wydziału Wojewódzkiego w Białymstoku w dniach 27 i 28 września postanowiono osoby zakonne obsługujące zakłady opiekuńcze w Supraślu i dom starców w Białymstoku zastąpić personelem świeckim ${ }^{17}$. Dwa miesiące później częściową informację na ten temat (tzn. tylko o laicyzacji Miejskiego Zakładu dla Dziewcząt w Supraślu) podało „Życie Białostockie" 18 .

15 Dom Dziecka $w$ Zwierzyricu. Sierotki z ulicy Sitarskiej w nowej siedzibie, „Życie Białostockie" nr 95 (938), 6 czerwca 1947, s. 4.

16 AP w B, KW PPR, syg. 1/II/1, Protokół posiedzenia plenarnego rozszerzonego KW PPR w Białymstoku w dniu 16 października 1947 r., s. 4:

17 AP w B, Wojewódzki Komitet Polskiej Partii Socjalistycznej w Białymstoku [dalej: WK PPS], syg. 67, Protokół posiedzenia Wydziału Wojewódzkiego w Białymstoku odbytego w dniach 27 i 28 września 1948 r., s. 14.

18 Dzięki budowie nowego Domu Dziecka opieka nad sierotami przyjmie właściwy kierunek wychowawczy, „Życie Białostockie” nr 322 (1464), 22 listopada 1948, s. 3. 
Inną ścieżką laicyzacji sektora opiekuńczo-wychowawczego było tworzenie, obok kościelnych, zakładów świeckich, które z czasem przejmowały od tych pierwszych podopiecznych wraz z potrzebnymi na ich utrzymanie funduszami. Jesienią 1947 r. Wojewódzka Rada Narodowa (WRN) i Wydział Wojewódzki w Białymstoku zajęły się przygotowaniem takiej operacji w skali województwa.

Prezydium WRN w Białymstoku uchwałą z dnia 8 października 1947 r. zleciło Wydziałowi Wojewódzkiemu opracowanie projektu powołania Związku Międzykomunalnego dla budowy i prowadzenia świeckich zakładów opiekuńczych i opiekuńczo-wychowawczych. 21 października 1947 r. na posiedzeniu Wydziału Wojewódzkiego w Białymstoku postanowiono:

a) nie tworzyć specjalnego Związku Międzykomunalnego, a zadania dla niego przewidziane powierzyć istniejącemu Wojewódzkiemu Związkowi Samorządowemu;

b) wystąpić z wnioskiem do WRN o powzięcie uchwały o utworzeniu wojewódzkiej sieci zakładów opiekuńczo-wychowawczych dla dzieci, młodzieży i starców.

W pierwszej kolejności zamierzano utworzyć domy dziecka dla sierot „po poległych w walce o niepodległość i demokrację". Ustaleniem ilości miejsc i rodzajów zakładów, jakie winny powstać, miała zająć się Wojewódzka Komisja Opieki Społecznej przy współudziale przedstawicieli Kuratorium Okręgu Szkolnego Białostockiego oraz Wydziału Opieki Społecznej i Wydziału Odbudowy Urzędu Wojewódzkiego Białostockiego ${ }^{19}$.

WRN 30 czerwca 1948 r. (na wniosek Wydziału Wojewódzkiego) zwróciła się do Powiatowych Rad Narodowych w Suwałkach, Bielsku Podlaskim, Łomży, Augustowie, Białymstoku i Olecku oraz do Miejskiej Rady Narodowej w Białymstoku z wezwaniem „[...] do niezwłocznego wszczęcia kroków celem uruchomienia, w miarę możliwości jeszcze w roku bieżącym, własnych domów dla sierot w wieku szkolnym" ${ }^{20}$. Dom dziecka w powiecie suwalskim miał obsługiwać także powiaty sokólski i grajewski, w powiecie bielskim - również wysokomazowiecki, w powiecie łomżyńskim - powiat kolneński, a w powiecie ełckim - powiaty olecki i gołdapski. W uzasadnieniu WRN stwierdziła „[...] że Zw. Sam. [Związki Samorządowe] sprawują dotąd opiekę nad sierotami poprzez różne organizacje charytatywne, zrzeszenia religijne,

19 AP w B, WK PPS, syg. 67, Protokół posiedzenia Wydziału Wojewódzkiego w Białymstoku w dniu 21 października 1947 r., s. 1-3.

20 AP w B, WK PPS, syg. 68, Protokół posiedzenia Wojewódzkiej Rady Narodowej w Białymstoku w dniu 30 czerwca 1948 r., s. 4-5. 
bądź to tzw. rodziny zastępcze, które nie dają gwarancji odpowiedniego wychowania i przysposobienia sierot do życia samodzielnego" ${ }^{21}$. Kosztowne tworzenie nowych zakładów opieki społecznej tylko po to, aby móc zlikwidować istniejące placówki kościelne, było nie tylko oburzającym aktem samowoli władz, ale i skandalicznym marnotrawstwem środków publicznych.

Odbieranie wychowanków domom dziecka prowadzonym przez zgromadzenia zakonne rozpoczęło się jeszcze w 1948 r. Kwestię tę omawiano na posiedzeniu egzekutywy KW PPR w Białymstoku w rozszerzonym składzie 5 września 1948 r., na którym jedynym punktem obrad było sprawozdanie ministra spraw zagranicznych tow. Modzelewskiego ze spotkania Komitetu Centralnego partii. Dyskutanci (towarzysze Citek, Sikora, Łaszewicz, Kubiak, Rubeńczyk, Dobrowolski, Kozłowski, Ossoliński, Machina) uznali, że konieczne jest,$[. .$.$] wyrwanie sierot z$ wpływów kleru i przejęcie nad nimi opieki przez Państwo [...]" ${ }^{22}$.

Przejmowanie podopiecznych zakładów katolickich przez świeckie placówki zostało poprzedzone publikacjami w lokalnej prasie przedstawiającymi w złym świetle sierocińce zakonne. W czerwcu 1948 r. „Życie Białostockie” nagłośniło zarzuty Komisji Opieki Społecznej przy Miejskiej Radzie Narodowej w Białymstoku wobec prowadzonego przez księży salezjanów w Supraślu domu dziecka dla chłopców, który był subsydiowany przez białostocki zarząd miasta. Księży oskarżono o brudy, wy jątkowe niechlujstwo, brak księgowania żywności i średniowieczne metody wychowawcze ${ }^{23}$. Co do ostatniego zarzutu artykuł nie wyjaśniał, czy chodziło o stosowanie kar fizycznych, czy też o „przerost” elementów religijnych w wychowaniu ${ }^{24}$. Zarzut nieksięgowania żywności był $\mathrm{w}$ istocie błahy, ale mógł on sugerować istnienie nadużyć finansowych. Natomiast oskarżenie salezjan o brudy i wyjątkowe niechlujstwo było zwyczajnym oszczerstwem, gdyż we wcześniejszych tekstach prasy białostockiej pisano bardzo pochlebnie o sierocińcu salezjań-

21 Ibidem.

22 AP w B, KW PPR, syg. 1/IV/2, Protokół posiedzenia egzekutywy KW PPR w Białymstoku w rozszerzonym składzie w dniu 5 września 1948 r., s. 2.

23 Średniowieczne metody wychowawcze. Stosowane sq w Domu Dziecka dla chtopców w Supraslu, „Życie Białostockie” nr 171 (1313), 23 czerwca 1948, s. 3.

24 W artykule „Życia Białostockiego” z marca 1948 r. na temat zwolnienia ze stanowiska kierowniczki domu dziecka w Suwałkach sformułowanie „średniowieczne metody wychowawcze" oznaczało używanie rózgi wobec nieposłusznych dzieci (Średniowieczne metodyw Domu Dziecka w Șuwałkach, „Życie Białostockie” nr 64 (1206), 5 marca 1948, s. 4.). 
skim, a nawet chwalono go za czystość i wy jątkowy komfort jak na warunki powojenne ${ }^{25}$.

W październiku 1948 r. prasa białostocka opublikowała oskarżenia pod adresem personelu sierocińca „Dobry Pasterz” 26. Białostocka delegatura Komisji Specjalnej do Walki z Nadużyciami i Szkodnictwem Gospodarczym zarzuciła magazynierce zakładu handel dziecięcą bielizną z darów i przywłaszczenie sobie pieniędzy z ich sprzedaży, a kierowniczce Eleonorze Wojtkowskiej - ciche przyzwolenie na handel darami i zaniedbania w buchalterii. Magazynierka Józefa Potocka 21 października została aresztowana, a jej sprawę w trybie doraźnym przekazano do Sądu Okręgowego w Białymstoku ${ }^{27}$. Wydaje się mało prawdopodobne, aby oskarżenia były prawdziwe, ale z punktu widzenia ówczesnego czytelnika ich wiarygodność była niesprawdzalna, a to już wystarczało, by popsuć opinię zakładu.

Publikacje w prasie białostockiej o rzekomych niedociągnięciach w sierocińcu „Dobry Pasterz” i supraskim ośrodku salezjanów były częścią ogólnokrajowej kampanii propagandowej szkalującej katolickie zakłady opiekuńcze. Laicyzacji opieki społecznej od czerwca 1948 r. towarzyszyła nie przebierająca w środkach akcja propagandowa, w której starano się podważyć zaufanie społeczeństwa do placówek opiekuńczo-wychowawczych prowadzonych przez Kościół. Osoby duchowne zajmujące się dziećmi i młodzieżą oskarżono o niezapewnianie podopiecznym właściwych warunków życia, o niegospodarność, stosowanie kar fizycznych, a nawet o nadużycia obyczajowe. Zarzuty wysuwane przez prorządową prasę miały być koronnym argumentem za zeświecczeniem sektora opiekuńczo-wychowawczego ${ }^{28}$.

25 Np. J. M. Kobus, Uśmiechnięte twarze z Domu Dziecka. Wrażenia z zakładów wychowawczych w Supraślu, „Jedność Narodowa” nr 62 (153), 18 maja 1946, s. 4.

26 Trzeba wniknać w gospodarkę tego zakładu. Magazynierka z "Dobrego Pasterza” okradała systematycznie sieroty, „Życie Białostockie” nr 293 (1435), 23 października 1948, s. 3 .

27 AP w B, Komisja Specjalna do Walki z Nadużyciami i Szkodnictwem Gospodarczym Delegatura w Białymstoku 1946-1955, syg. 15, k. 283, 287; syg. 40, k. 15.

28 „Życie Białostockie” szczególny rozgłos nadało sprawom wokół zakładów braci albertynów w Warszawie [„Życie Białostockie” nr 165 (1307) z 17 czerwca 1948 r., nr 185 (1327) z 7 lipca 1948 r., nr 203 (1345) z 25 lipca 1948 r., nr 207 (1349) z 29 lipca 1948 r., n r 313 (1455) z 13 listopada 1948 r.] i ojców franciszkanów w Niepokalanowie [„Życie Białostockie" nr 189 (1331) z 11 lipca 1948 r., nr 293 (1435) z 23 października 1948 r., nr 304 (1446) z 4 listopada 1948 r., nr 305 (1447) z 5 listopada 1948 r.]. Trzem albertynom i franciszkaninowi zarzucono zmuszanie wychowanków do czynów nierządnych, jednego zakonnika z Warszawy sąd uniewinnił, a pozostali otrzymali wyroki od 3 do 6 lat więzienia. Wina skazanych (w dwóch typowo pokazowych procesach) była jednak bardzo problematyczna, zważywszy, że akurat od połowy 1948 r., jak na zawołanie, zaczęły się pojawiać z różnych stron kraju oskarżenia wobec duchownych o niemoralne prowadzenie się. 
O trwającej akcji likwidacji katolickich domów dziecka (bo właśnie to oznaczało odebranie im podopiecznych) „Życie Białostockie” poinformowało w drugiej połowie listopada 1948 r. Chłopcy z domu dziecka księży salezjanów w Supraślu mieli być przeniesieni do remontowanego obiektu w obrębie posiadłości szpitala psychiatrycznego w Choroszczy ${ }^{29}$. Dziewczęta z białostockiego sierocińca „Dobry Pasterz" i zakładu prowadzonego przez szarytki w Białymstoku (przy ul. Legionowej) sukcesywnie przenoszono do państwowych i samorządowych zakładów opiekuńczych. Gazeta decyzję władz uzasadniała ,[...] ogólnym współczesnym kierunkiem wychowawczy m, czego nie mogły zapewnić dotychczas zespoły wychowawcze rekrutujące się z członków bractw zakonnych" oraz dążeniem do zeświecczenia wychowania młodzieży ${ }^{30}$. Jakie korzyści wychowawcze i zdrowotne mogło przynieść ulokowanie osieroconych chłopców (mieszkających uprzednio w miejscowości o walorach uzdrowiskowych) w domu dziecka sąsiadującym z placówką dla umysłowo chorych?! Korzyści takie mogli widzieć tylko ludzie wdrażający „kierunek wychowawczy” oparty na obłąkanej ideologii.

W kręgach decydenckich województwa białostockiego istniała też koncepcja sekularyzacji zakonnych zakładów opiekuńczych przez ich upaństwowienie i przekazanie w zarząd świeckim stowarzyszeniom popieranym przez reżim. Zwolennikiem tej metody laicyzacji był naczelnik Wydziału Społeczno-Politycznego Urzędu Wojewódzkiego Białostockiego Cz. B. Matejko, człowiek odpowiedzialny za politykę urzędu wobec Kościoła katolickiego, znany wśród księży ze swego antyklerykalizmu ${ }^{31}$. W roku 1948 w ramach akcji zbierania danych o kościołach i związkach religijnych powstało opracowanie dotyczące działalności zakonów w województwie białostockim. W dokumencie tym, podpisanym przez Matejkę, w charakterystyce zgromadzenia sióstr Maŗyi w Augustowie (prowadzących domy dziecka w Augustowie i Studzienicznej, dom starców w Augustowie i pracujących w szpitalu powiatowym) czytamy: „W zakładach [prowadzonych przez zakon] do niedawna brak było godeł państwowych i portretów dostojników państwowych. Rewizja biblioteki w Domu Dziecka wykryła jedną książkę będącą na indeksie,

29 O likwidacji sierocińca salezjańskiego w Supraślu informowano jeszcze osobno w grudniu 1948 r.: Nowy Dom Dziecka wkrótce powstanie w Choroszczy, „Życie Białostockie" nr 350 (1492), 20 grudnia 1948, s. 4.

30 Dzięki budowie nowego Domu Dziecka opieka nad sierotami przyjmie właściwy kierunek wychowawczy, „Życie Białostockie” nr 322 (1464), 22 listopada 1948, s. 3.

31 AP w B, Urząd Wojewódzki Białostocki [dalej: UWB], syg. 668, k. 17, Donos do naczelnika Wydziału Społeczno-Politycznego UWB pracownicy wydziału D. Borowskiej na księdza Urbana z Białegostoku z marca 1948 r. 
którą skonfiskowano. Wpływ na dzieci ujemny, utrzymywany w duchu katol. [katolicko] narodowym. Należy dążyć do odebrania kierownictwa zakładów opiekuńczych i powierzyć te zadania R.T.P.D. i Ch.T.P.D." ${ }^{32}$. Wnioski zawarte w opracowaniu znalazły zastosowanie dopiero po roku 1948.

Szczególnym przypadkiem laicyzacji placówki opiekuńczo-wychowawczej było zerwanie przez Dyrekcję Lasów Państwowych (DLP), pod naciskiem władz politycznych, umowy z "Caritasem” o zarządzanie przedszkolem robotniczym należącym do przedsiębiorstwa. W białostockiej dzielnicy Dojlidy między lutym a kwietniem 1947 r. zostało zorganizowane przez Robotnicze Towarzystwo Przyjaciół Dzieci przedszkole, które niemal od razu oddano pod opiekę DLP. Z kolei DLP równie szybko przekazała zarząd nad przedszkolem miejscowemu "Caritasowi" na okres 5 lat ${ }^{33}$. Było to o tyle zaskakujące, że zarówno przewodniczącym zarządu białostockiego oddziału RTPD, jak i dyrektorem Lasów Państwowych był ten sam człowiek - inżynier Zygmunt Łukaszewicz, członek Wojewódzkiego Komitetu PPS w Białymstoku. Jesienią 1948 r., w momencie rozwijania się akcji zeświecczania opieki społecznej i zaostrzania się stosunków „władzy ludowej” z Kościołem, fakt zarządzania przez katolicką instytucję placówką będącą własnością państwowego przedsiębiorstwa wzbudził konsternację we władzach wojewódzkich PPS-u. Pierwszy sekretarz WK PPS w Białymstoku Andrzej Werblan w piśmie z 4 września 1948 r. zwrócił się z interwencją do dyrektora Lasów Państwowych towarzysza Łukaszewicza:

„Wojewódzki Komitet Polskiej Partii Socjalistycznej w Białymstoku zwrócił uwagę, że budynek przedszkola, który znajduje się w Dojlidach (własność D.L.P.) jest oddany pod zarząd «caritasu», którym zarządza ksiądz. Wskazanym byłoby ażeby kierownictwem przedszkoli zajęło się Robotnicze Towarzystwo Przyjaciół Dzieci. Dlatego też WK PPS zwrócił się do Oddz. R.T.P.D. w Białymstoku o wystąpienie w sprawie przejęcia zarządu w/w przedszkola i równocześnie prosi Towarzysza o poparcie starań R.T.P.D. w tym kierunku" 34 .

32 AP w B, syg. 666, k. 27, Zestawienie danych dotyczących działalności zakonów w województwie białostockim sporządzone w Wydziale Społeczno-Politycznym UWB w r. 1948.

33 Przedszkola i ogródki jordanowskie tworzy RTPD w Białymstoku, „Życie Białostockie" nr 43 (886), 14 kwietnia 1947, s. 4; 2300 dzieci w wieku przedszkolnym oczekuje na nowe przedszkola, „Życie Białostockie” nr 57 (900), 28 kwietnia 1947, s. 4.

34 AP w B, WK PPS, syg. 16, k. 165, Pismo I sekretarza WK PPS w Białymstoku Andrzeja Werblana do Dyrektora Lasów Państwowych tow. Zygmunta Łukszewicza z 4 września $1948 \mathrm{r}$. 
Natomiast $\mathrm{w}$ korespondencji do oddziału towarzystwa w Białymstoku tow. Werblan zalecał:

„Wskazanym byłoby ażeby Zarząd R.T.P.D. wszczął kroki w celu przejęcia przedszkola pod swoje kierownictwo. Zaznacza się przytem, że budynek przedszkola jest własnością D.L.P. i interwencje w tej sprawie należy kierować do D.L.P. Wojewódzki Komitet PPS ze swej strony poprze ten wniosek" 35 .

Miesiąc później, na posiedzeniu aktywistów WK PPS (w dniu 3 października) poświęconym samokrytyce, tow. Łukaszewicz musiał się mocno tłumaczyć: „Przedszkole w Dojlidach dałem dlatego Caritasowi bo nikogo innego nie było, zależało mi, aby dzieci robotników bawiące się w kurzu i błocie znalazły opiekę przedszkolną. Termin pięcioletniej umowy ma jedynie znaczenie formalne. Umowa będzie zerwana do 15.X.b.r." ${ }^{36}$.

Sprawa przedszkola w Dojlidach odbiła się echem na posiedzeniu Wydziału Wojewódzkiego w Białymstoku 20 października 1948 r., na którym na wniosek Izydora Kunata z KW PPR postanowiono „zwrócić uwagę Wydziałowi Opieki Społecznej [UWB] na niewłaściwość poruczania prowadzenia placówek opiekuńczych przez zrzeszenia religijne" ${ }^{37}$.

Władze województwa białostockiego były nastawione nieprzychylnie nie tylko do ośrodków pomocy społecznej prowadzonych przez zgromadzenia zakonne, ale także wobec działającego w strukturach diecezjalnych i parafialnych "Caritasu”. Od pierwszych miesięcy działalności tej organizacji jej szybki rozwój wzbudzał niezadowolenie najwyższych kręgów władzy politycznej województwa. Kierownictwo wojewódzkie Polskiej Partii Robotniczej na początku 1946 r. było tak bardzo zaniepokojone wzrastającą aktywnością „Caritasu”, że na posiedzeniu egzekutywy KW PPR 2 lutego 1946 r. postanowionọ włączyć do miesięcznego sprawozdania za styczén następujące zdanie: „Duchowieństwo na terenie województwa coraz agresywniej występuje przeciw państwu, kler zakłada coraz nowsze organizacje jak Caritas do których wciska swoich ludzi [...]" ${ }^{38}$.

35 AP w B, WK PPS, syg. 31, k. 453, Pismo I sekretarza WK PPS w Białymstoku Andrzeja Werblana do Oddziału RTPD w Białymstoku z 4 września 1948 r.

36 AP w B, WK PPS, syg. 10, Protokół posiedzenia aktywistów WK PPS w Białymstoku w dniu 3 października 1948 r., s. 15.

37 AP w B, WK PPS, syg. 67, Protokół posiedzenia Wydziału Wojewódzkiego w Białymstoku w dniu 20 października 1948 r., s. 3.

38 AP w B, KW PPR, syg. 1/IV/1, Protokół posiedzenia egzekutywy KW PPR w Białymstoku w dniu 2 lutego 1946 r., s. 2; AP w B, KW PPR, syg. 1/V/6, Sprawozdanie miesięczne KW PPR w Białymstoku za styczeń 1946 r., s. 4. 
Chociaż sekularyzacja opieki społecznej przed rokiem 1949 nie zagroziła "Caritasowi" tak bardzo jak placówkom zakonnym, to był on także narażony na szykany ze strony komunistycznych władz. Przykładem tego są, opisane powyżej, zajęcie domu kościelnego w Brańsku przez milicję i odebranie kierownictwa przedszkola w Dojlidach. Innym świadectwem dyskryminacji "Caritasu" były utrudnienia w zorganizowaniu w dniach 3-10 października 1948 r. Tygodnia Miłosierdzia, tradycy jnie łączącego imprezy charytatywne i kulturalne z przeżyciami religijnymi.

W roku 1948 centralne władze państwowe postanowiły zredukować obchody Tygodnia Miłosierdzia wyłącznie do publicznych zbiórek pieniężnych. W tym celu Departament Polityczny Ministerstwa Administracji Publicznej 14 września wydał tajne zarządzenie dla wojewodów, w którym polecono: „[...] władze administracji ogólnej winny nie zezwalać na urządzanie imprez (akademii, odczytów, przedstawień i.t.p.) w tych miejscowościach, w których kierownicy ośrodków miejscowych «Caritasu» względnie członkowie swoim zachowaniem się i postawą wobec dzisiejszej rzeczywistości nie dają pełnej gwarancji, że ograniczą się do akcji charytatywnej z pominięciem jakichkolwiek momentów politycznych. Za niewłaściwe uważa Ministerstwo również udział przedstawicieli władz w komitetach organizacyjnych, względnie imprezach" ${ }^{39}$. 17 września wicewojewoda białostocki Wacław Białkowski przekazał starostom powiatowym, prezydentowi Białegostoku oraz szefowi Wojewódzkiego Urzędu Bezpieczeństwa Publicznego w Białymstoku i wojewódzkiemu komendantowi MO zalecenia ministerstwa ${ }^{40}$.

W efekcie zarządzenia starosta bielski nie zezwolił oddziałowi "Caritasu” w Brańsku na publiczne odegranie sztuki Zofii Kossak „Gość oczekiwany". Starosta łomżyński odmówił zambrowskiemu oddziałowi "Caritasu" zgody na zorganizowanie zabawy tanecznej 23 października pod pretekstem zarezerwowania tego dnia przez RTPD. W powiecie augustowskim „Caritas” Diecezji Łomżyńskiej został zmuszony do przeniesienia kwesty na listopad z powodu prowadzenia w październiku przez władze innych zbiórek. W Białymstoku oddziałowi „Caritas” parafii Farnej uniemożliwiono przeprowadzenie 10 października akademii w sali Teatru Miejskiego. Impreza

39 AP w B, UWB, syg. 678, k. 2, Tajne pismo Departamentu Politycznego Ministerstwa Administracji Publicznej z 14 września 1948 r. do wszystkich wojewodów w sprawie Tygodnia Miłosierdzia „Caritas”.

40 AP w B, UWB, syg. 678, k. 4, Tajne pismo wicewojewody białostockiego z 17 września 1948 r. do wszystkich starostów powiatowych i prezydenta Białegostoku w sprawie Tygodnia Miłosierdzia „Caritas”. 
uzyskała zezwolenie Wojewódzkiego Urzędu Kontroli Prasy Publikacji i- Widowisk oraz Zarządu Miejskiego, ale nie dopuściła do niej milicja, zajmując salę na własną akademię ${ }^{41}$.

Władze komunistyczne znacząca rolę w procesie laicyzacji wyznaczyły Robotniczemu Towarzystwu Przy jaciół Dzieci, działającemu na terenie miejskim, i jego wiejskiemu odpowiednikowi Chłopskiemu TPD (obydwa połaczono w 1949 r. w Towarzystwo Przyjaciół Dzieci). Zadania RTPD i jego ideologiczno-polityczne oblicze trafnie charakteryzował okólnik sekretariatu KC PPR z 22 października 1947 r., w którym towarzystwo nazwano „jednolitofrontową organizacją robotniczą, kierowaną solidarnie przez obydwie Partie robotnicze, posiadającą uprawnienia instytucji publicznej" ${ }^{42}$. Dokument wśród zasadniczych celów RTPD wymieniał organizowanie i prowadzenie „[...] postępowych placówek wychowawczych dla dzieci i młodzieży robotniczej [...] mających spełniać pionierską rolę w torowaniu najbardziej postępowych form i metod wychowawczych" ${ }^{43}$. Jednak najważniejsze były zadania ideologiczne: „RTPD powołane jest do rozpracowania podstaw ideologicznych, metod i form pedagogiki marksistowskiej, do unicestwienia zgubnych wpływów reakkcji na dzieci i młodzież robotniczą, do rozwijania w nich światopoglądu socjalistycznego, do wychowania ich na entuzjastów i bojowników sprawy robotniczej" 44.

RTPD i ChTPD w województwie białostockim przed 1949 r. zajmowały się wyłącznie sektorem opiekuńczo-wychowawczym. W Białymstoku Oddział RTPD formalnie został powołany 5 lipca 1946 r. z inicjatywy kuratora OSB E. Krassowskiej (w zarządzie znaleźli się przedstawiciele partii politycznych, kuratorium, związków zawodowych, Ligi Kobiet) ${ }^{45}$. Faktyczną pracę białostockie RTPD rozpoczęło dopiero od 15 lutego 1947 r., gdy utworzono nowy zarząd oddziału (z Z. Eukaszewiczem na czele) ${ }^{46}$. Kolejne

41 AP w B, UWB, syg. 678, k. 22, Odpis tajnego sprawozdania z przebiegu Tygodnia Miłosierdzia "CARITAS” na obszarze województwa białostockiego przesłanego przez naczelnika Wydziału Społeczno-Politycznego UWB do Departamentu Politycznego Ministerstwa Administracji Publicznej pismem z dnia 19 listopada 1948 r.

42 AP w B, KW PPR, syg. 1/VII/6, Okólnik Nr 51 Sekretariatu KC PPR z 22 października 1947 r. do sekretarzy wojewódzkich, miejskich i powiatowych komitetów PPR w sprawie udziału Partii w działalności RTPD.

43 Ibidem.

44 Ibidem.

45 Oddział R.T.P.D. w Białymstoku, „Jedność Narodowa” nr 104 (195), 7 lipca 1946, s. 6 .

46 Przedszkola i ogródki jordanowskie tworzy RTPD w Białymstoku, „Życie Białostockie” nr 43 (886), 14 kwietnia 1947, s. 4. 
zmiany zarządu odbyły się wiosną 1947 r. i w styczniu 1948 r. ${ }^{47}$ Działalność towarzystwa w latach 1947-1948, w porównaniu z rozmachem "Caritasu" (zważywszy, że władze faworyzowały RTPD), była raczej skromna i ograniczała się niemal wyłącznie do Białegostoku. W okresie tym w woj. białostockim RTPD nie udało się rozwinąć sieci placówek terenowych (prawdopodobnie przed r. 1949 jedyna aktywna filia towarzystwa istniała w Ełku) ${ }^{48}$. W 1947 r. RTPD zorganizowało przedszkole w Dojlidach (przekazane szybko "Caritasowi" i odebrane w 1948 r.), ogródek jordanowski przy ul. Mickiewicza, rozpoczęło budowę „wzorcowego przedszkola” przy ul. Wasilkowskiej i świetlicy przy ul. Konopnickiej. W 1948 r. towarzystwo objęło patronatem przedszkole przy ul. Grottgera i założyło przedszkole w Gródku ${ }^{49}$. W prasie lokalnej często pojawiały się artykuły lub wzmianki promujące organizację i zachęcające do finansowego jej wspierania. Szczególnie intensywnie reklamowano towarzystwo przy okazji „Dnia RTPD” - 26 października, którego obchody w 1947 r. białostocki oddział przeprowadził w ramach „Miesiąca Wymiany Kulturalnej z ZSRR" 50. Chłopskie Towarzystwo Przy jaciół Dzieci, w kraju działające od 1946 r., w woj. białostockim powołano dopiero jesienią 1947 r. i chociaż na czele komitetu organizacy jnego stanął wojewoda, to nie odgrywało ono znaczącej roli ${ }^{51}$.

Ateizacja w zakładach opiekuńczych prowadzona była nie tylko pod egidą RTPD, zwalczaniem religii zajmowało się również Kuratorium Okręgu Szkolnego Białostockiego. Świadczy o tym sprawozdanie KOSB z osiągnięć „na odcinku" wychowania przedszkolnego w okresie od września 1945 r. do czerwca 1948 r. Dokument ten stwierdza, że praca wychowawcza w placówkach nastawiona była na zapoznanie dzieci $z$ „naukowym poglądem materialistycznym", czemu służyło "nasilenie tematyki przyrodniczej z zastosowaniem obserwacji, hodowli” i „likwidacja przerostów dewocy jnych”. Sprawo-

47 RTPD ma nowy Zarząd, „Życie Białostockie” nr 100 (943), 11 czerwca 1947, s. 3; Nowe placówki RTPD zapewniaja opiekę dzieciom robotniczym, „Życie Białostockie” n r 25 (1167), 25 stycznia 1948, s. 3.

48 R.T.P.D. powstaje w Ełku, „Życie Białostockie” nr 178 (1021), 28 sierpnia 1947, s. 3; Problem wychowania dzieci znalazł swój wyraz w działalności R.T.P.D., „Życie Białostockie" nr 240 (1083), 29 października 1947, s. 3.

49 Patrz: przypisy 47-49; W trosce o dziecko robotnicze, „Życie Białostockie” nr 89 (1231), 1 kwietnia 1948, s. 3.

50 „Życie Białostockie” nr 220 (1063) z 9 października 1947 r., n r 226 (1069) z 15 października 1947 r., nr 228 (1071) z 17 października 1947 r., nr 237 (1080) z 26 października 1947 r., nr 238 (1081) z 27 października 1947 r., nr 240 (1083) z 29 października 1947 r.

51 Niezamożne dzieci chtopskie otrzymaja pomoc materialnq i kulturalna, „Życie Białostockie" nr 243 (1056), 1 listopada 1947, s. 3. 
zdanie wśród potrzeb okręgu wymieniło konieczność przeszkolenia na kursach ideologicznych wszystkich wychowawczyń przedszkolnych ${ }^{52}$.

Z sekularyzacją sektora opiekuńczo-wychowawczego związana była tajna akcja zbierania danych o działalności Kościoła katolickiego (i innych wyznań), zapoczątkowana przez Departament Polityczny Ministerstwa Administracji Publicznej w lutym 1948 r. ${ }^{53} \mathrm{~W}$ marcu 1948 r. do akcji przyłączyło się też Ministerstwo Ziem Odzyskanych (Departament Administracji Publicznej), które w województwie białostockim sprawowało nadzór nad powiatami: ełckim, gołdapskim i oleckim ${ }^{54}$. Oba ministerstwa zwróciły się do wojewodów (m.in. do białostockiego) o zebranie i dostarczenie do 31 lipca 1948 r., a później aktualizowanie, szeregu informacji (oraz przesyłanie co kwartał sprawozdań o zaszłych zmianach), a wśród nich dotyczących charytatywno-opiekuńczej aktywności Kościoła katolickiego. Gromadzeniem odpowiednich danych zajął się Wydział Społeczno-Polityczny Urzędu Wojewódzkiego Białostockiego za pośrednictwem starostów powiatowych i prezydenta Białegostoku ${ }^{55}$. Ministerstwa zażądały m.in. wykazu zakładów opiekuńczych i wychowawczych prowadzonych przez zakony i inne związki religijne (wraz z opisem), wykazu sióstr zakonnych zatrudnionych na terenie szpitali, informacji o składzie zarządów diecezjalnych "Caritasu” (z charakterystyką poszczególnych osób) oraz o działalności oddziałów tej organizacji. Zebrane dane posłużyły przygotowaniom do laicyzacji placówek opiekuńczo-wychowawczych przeprowadzanej w roku 1948 i w latach następnych.

Już w dwóch pierwszych latach po wojnie (1945 i 1946) władze województwa białostockiego wykazywały antyklerykalne nastawienie, utrudniając Kościołowi katolickiemu działalność na polu opieki społecznej. W roku 1947 szykany wobec katolickich zakładów opiekuńczych wzmogły się, a w 1948 r. akcja laicyzacyjna nabrała prawdziwego rozmachu.

52 AP w B, KOSB, syg. 88, Sprawozdanie KOSB z osiągnięć okręgu na odcinku wychowania przedszkolnego za okres od września 1945 r. do czerwca 1948 r., s. 4, 7.

53 AP w B, UWB, syg. 666, k. 1, Tajne pismo Departementu Politycznego Ministerstwa Administracji Publicznej do wojewodów z 14 lutego 1948 r. w sprawie danych o kościołach i związkach religijnych.

54 AP w B, UWB, syg. 667, k. 2, Poufne pismo Departamentu Administracji Publicznej Ministerstwa Ziem Odzyskanych do wszystkich wojewodów na obszarze Ziem Odzyskanych z 24 marca 1948 r.

55 AP w B, UWB, syg. 666, k. 5, Tajne pismo Wydziału Społeczno-Politycznego UWB do Starostw Powiatowych i Prezydenta m. Białegostoku z 23 lutego 1948 r. w sprawie danych o kościołach i związkach religijnych; AP w B, UWB, syg. 666, k. 11, Tajne pismo Wydziału Społeczno-Politycznego UWB do Starostów Powiatowych w Ełku, Olecku i Gołdapi z 13 kwietnia 1948 r. w sprawie danych o kościołach i związkach religijnych. 
Przed rokiem 1949 działania reżimu zmierzające do sekularyzacji opieki społecznej były wymierzone w woj. białostockim przede wszystkim w działalność opiekuńczą zakonów męskich i żeńskich (m.in. szarytek i salezjanów). W okresie tym władze skoncentrowały się na lạicyzacji domów dziecka (i burs dla sierot, prowadzonych często razem z sierocińcami, jak w przypadku zakładów księży salezjanów i szarytek). Zakłady innego rodzaju (domy starców, przedszkola) akcja zeświecczania objęła na większą skalę po roku 1948. Także działalność charytatywno-opiekuńcza organizowana w ramach "Caritasu" napotykała przed rokiem 1949 na przeszkody ze strony władz komunistycznych, jednak walka z tą organizacją przybrała na sile dopiero w okresie następnym.

W trakcie laicyzacji opieki społecznej w latach 1945-1948 priorytetowo potraktowano sektor opiekuńczo-wychowawczy, co nie było dziełem przypadku, ale świadomą realizacją ogólnych priorytetów antykościelnej polityki „władzy ludowej”, w której pierwszoplanowe miejsce zajmowała walka o przejęcie kontroli nad młodym pokoleniem. Instytucjom katolickim i osobom duchownym odbierano możliwość opieki nad dziećmi po to, aby równocześnie odebrać im możliwość oddziaływania wychowawczego. I chociaż oficjalnie zeświecczanie systemu pomocy dzieciom motywowano głównie koniecznością zapewnienia lepszej opieki, to w rzeczywistości decydowano się nawet na pogorszenie warunków opiekuńczych, byle tylko wyrwać dzieci spod wpływu Kościoła i móc je swobodnie kształtować podług apriorycznie wykoncypowanego modelu ideologicznego. Był to wyraźny przykład szkodliwości stosowania inżynierii społecznej, przekształcania naturalnych organizmów społecznych siłą, bez liczenia się z prawdziwymi potrzebami ludzi, zarówno duchowymi, psychicznymi, jak i materialnymi. Zaznaczyć trzeba, iż laicyzację wdrażano nie tylko wbrew woli osób, których dotyczyła, ale często także przy braku poszanowania obowiązującego prawa.

Utrudnianie i ograniczanie działalności charytatywno-opiekuńczej organizacji katolickich i zakonów przez komunistyczny reżim było wyjątkowo dotkliwe dla Kościoła, gdyż niesienie materialnej pomocy ubogim i potrzebującym stanowiło zawsze istotny element jego doczesnej misji. Szczególnie negatywne konsekwencje duchowe, psychiczne i moralne niosło. odseparowanie sierot od ich opiekunów ze stanu duchownego, ponieważ dzieci te pozbawione przez wojnę i inne okoliczności życiowe normalnego środowiska rodzinnego - były bardziej podatne na indoktrynację od rówieśników czerpiących wzorce kulturowe nie tylko w szkole i kościele, ale przede wszystkim w domu. 
$\mathrm{Na}$ zakończenie należy podkreślić, iż żeświecczanie opieki społecznej oraz innych sfer życia publicznego było częścią szerszego procesu zniewalania społeczeństwa polskiego wykonywanego przez obóz polityczny współpracujący z sowieckim okupantem, a lata 1945-1948 początkiem powojennej niewoli. Nie można zapominać, że w pierwszym etapie stalinizmu obok względnie subtelnych form ubezwłasnowolniania Polaków, takich jak laicyzacja, szalał nie przebierający w środkach terror skierowany przeciwko środowiskom niepodległościowym. Nie sposób jednak nie zauważyć, że swoiste dokonywanie gwałtu na duchowości narodu poprzez ateizację było podobnie bezwzględne i brutalne jak akty fizycznego wyniszczania niepokornych jednostek. 